\title{
Severe Acute Respiratory Syndrome (SARS-CoV-2): A national public health emergency and its impact on food security in Peru
}

\author{
Ligia García ${ }^{1}$; Jaris Veneros ${ }^{2} \mathbb{D}$; Daniel Tineo ${ }^{3,{ }^{*} \mathbb{D}}$ \\ 1 Instituto de Investigación, Innovación y Desarrollo para el Sector Agrario y Agroindustrial de la Región Amazonas \\ (IIDAA), Universidad Nacional Toribio Rodríguez de Mendoza, Chachapoyas, Amazonas, Peru. \\ 2 Landscape Biodiversity Lab, Montana State University, Bozeman, Montana, United States. \\ 3 Instituto de Investigación para el Desarrollo Sustentable de Ceja de Selva (INDES-CES), Universidad Nacional Toribio \\ Rodríguez de Mendoza, Chachapoyas, Amazonas, Peru.
}

Received April 22, 2020. Accepted May 12, 2020.

\begin{abstract}
On March 16, 2020, a policy of quarantine and social isolation initiated in Peru imposed by the declaration of National Public Health Emergency for Severe Acute Respiratory Syndrome (SARS-CoV-2), which is affecting everyone. The research aimed to collect information that anticipates the impacts on the quantity and the need to distribute food for food security. From a global point of view, fiscal, monetary, and macro-financial policies corresponding to approximately $7 \%$ of the National GDP. These efforts will be insufficient if they are not complemented by adequate planning to supply the needs of Peru with at least 484,402.1 kilos of food per month, concerning agricultural products contained in the index basket and that need to be distributed in all regions of the country, such as rice, potatoes and at least 14 other products. In conclusion, measures in four aspects are urgent: technological, scientific, humanitarian, and planning, in addition to those implemented, to mitigate the impacts on food security, now and postpandemic, it is suggested that the issue should be treated from a transdisciplinary perspective.
\end{abstract}

Keywords: SARS-CoV-2; COVID-19; coronavirus; public health; food security.

\section{Introduction}

The Severe Acute Respiratory Syndrome (SARS-CoV-2) named by the International Committee of Taxonomy of viruses and today known as Coronavirus 2019 (COVID19) named by the World Health Organization (WHO) (Deng and Peng, 2020), although due to its capacity for infection (Zhu et al., 2020) makes it a disease classified as a global public health emergency (WHO, 2020). Today thousands of human lives and livelihoods are at risk in the face of this pandemic, which requires a global response (Siche, 2020; WHO, 2020). A problem that affects the supply and demand for food due to the closure of borders, quarantines, the supply chain, and global trade, at a global level (WHO, 2020). In any scenario, the poorest segments of the population are the most vulnerable. What is more, restrictions on INEI, as well as basic behavior of aversion, the shortage of fertilizers affects directly agricultural production in terms of quality, safety, and sustainability as the disease progresses (Siche, 2020; Chen et al., 2020). There is also the deficiency of agricultural systems on a global scale, which requires the implementation of different strategies and technologies to avoid loss of food (Shafiee-Jood and Cai, 2016; Wunderlich and Martínez, 2018).

This study analyzes the impact of the pandemic on key indicators for food security, understood as strategies for disaster prevention, crisis, and the ability to cushion the impacts that allow sustaining the availability of food in quantity and quality

Cite this article:

García, L.; Veneros, J.; Tineo, D. 2020. Severe Acute Respiratory Syndrome (SARS-CoV-2): A national public health emergency and its impact on food security in Peru. Scientia Agropecuaria 11(2): 241-245. 
(WHO, 2020) during and after the health emergency in Peru. Likewise, analyzing opportune tools that include the sustainability of the stores and markets of basic food supplies in the country, during and after the SARS-CoV-2 pandemic.

\section{SARS-CoV-2 and Food Security in Peru: Timeline}

The first confirmed case of COVID-19 in Peru was on March 6, and by May 9, 2020 it has infected a total of $3,759,967$ confirmed cases, and 259,474 deaths worldwide (WHO, 2020), of which 65,847 infected and 1,714 dead are in Peru (MINSA, 2020a). This situation affected the economic, social, political, cultural aspects, becoming a problem to be solved at a transdisciplinary level. Firstly, it is being related to human ecology, understood as the focus of the study of humans as biological and social organisms that interact with their environment that emphasizes the creation, use and management of resources for creative adaptation, human development and sustainability of environments (Bubolz, Sontag, 2009). By their nature highly transmissible due to its current exponential growth in infections (Zhao et al., 2020), the governing authorities, in most countries, have focused on the implementation of strategies to save human lives.

This is reported by the International Monetary Fund (IMF, 2020), which tracks the key policy response by the Emergency to SARS-CoV-2 in 153 economies around the world. Although, the tracker focuses on discretionary actions and may not fully reflect the policies adopted by countries in response to COVID-19, we consider that they are the most important measures that have been adopted in the world.

In the face of the pandemic, Peru declared a National State of Emergency with preventive measures in the economic, social, educational, and health fields, using a series of policies at the fiscal, monetary, macrofinancial, exchange rate, and balance of payments actions that would bring total fiscal support to approximately $7 \%$ of GDP (IMF, 2020). In this sense in March 11, 2020, the Peruvian Government issued a series of decrees and actions to combat SARS-CoV2 , several of them related to actions for food security and food availability.

Making a relationship to SARS-CoV-2 with the availability of food in Peru, it has been determined that the supply remained stable from day 1 of the COVID report to March 31, 2020 (Siche, 2020), even for April, even though the price index decreased for the third consecutive month in the year (FAOa,
2020), related to weak demand and the fall in oil prices due to the pandemic (FAOb, 2020).

This scenario could change from April to May 2020 (FAO, 2020c), causing that economic impacts on food security in Peru, due to SARS-CoV-2, become less important, and should be reviewed, only after prioritizing possible impacts on human ecology; as is malnutrition, and hunger. Food restrictions are alerted due to the closure of borders, quarantines, market interruptions, and low distribution of nutritious, diverse, and sufficient food (FAO, 2020c).

So, these efforts are not enough, since at the date of presentation of this study the contagion curve does not flatten. This leads to considering a greater number of challenges that face food security and its resilience (expost) at the Country level as well as the changes that may occur at the level of agricultural foreign trade in a globalized world.

\section{Minimum nutritional requirements in Perú}

Taking into account data such as the reduction of the General Index of Producer Prices by $-0.54 \%$ that occurred in 2019 (INEI, 2020a), and increases in the consumer price index are revealed in March 2020, with a variation of $0.61 \%$ at the national level, and an accumulated of $0.78 \%$ as an increase in the first 3 months of the year (INEI, 2020a). Is important the data in Table 1. There are 17 reference products, considered for more than 20 years in the minimum index basket of Peruvian consumption, belonging to the basic food group (INEI, 2020b) and which are repeated in all index baskets per average inhabitant within a geographic context. Rice and potatoes are the most consumed products in the different geographical domains of Peru (Table 1). Rice is considered one of the most important basic foods in the world (Maione and Megaço, 2019), and potato, as the most important vegetable in the world, which only follows wheat and rice as a food crop (Jansky et al., 2019). Rice is recognized in the country as the main food at the rural level, surpassing a current diversified supply of products, occupying more than a third of annual per capita consumption (Rosales and Mercado, 2020). Peru has great genetic variation of crop species (Velásquez-Milla et al., 2011). Salt and sugar have also been considered as an object of analysis as they are complementary products (Mouquet et al., 2003). Data must be revised now so that national decrees from the National Emergency by SARS -CoV2, can be effectively implemented. 
Table 1

Monthly food need $(\mathrm{kg})$ of products from the agricultural subsector including salt and sugar considered essential, which are repeated in all index baskets per average inhabitant

\begin{tabular}{|c|c|c|c|c|c|c|c|c|}
\hline Product & Lima & $\begin{array}{l}\text { Rural } \\
\text { Sierra }\end{array}$ & $\begin{array}{l}\text { Urban } \\
\text { Sierra }\end{array}$ & $\begin{array}{c}\text { Rural } \\
\text { Jungle }\end{array}$ & $\begin{array}{c}\text { Urban } \\
\text { Jungle }\end{array}$ & $\begin{array}{l}\text { Urban } \\
\text { Coast }\end{array}$ & $\begin{array}{l}\text { Rural } \\
\text { Coast }\end{array}$ & Average \\
\hline Oat & 0.345 & 0.246 & 0.279 & 0.201 & 0.159 & 0.237 & 0.279 & 0.249 \\
\hline Tomato & 0.48 & 0.429 & 0.471 & 0.702 & 0.63 & 0.564 & 0.684 & 0.566 \\
\hline Celery & 0.129 & 0.195 & 0.21 & 0.21 & 0.1 & 0.15 & 0.186 & 0.169 \\
\hline Head onion & 0.867 & 0.573 & 0.585 & 0.6 & 0.63 & 0.717 & 0.822 & 0.685 \\
\hline Coriander & 0.081 & 0.123 & 0.126 & 0.132 & 0.087 & 0.066 & 0.084 & 0.1 \\
\hline Banana & 1.182 & 0.687 & 0.834 & 1.683 & 0.981 & 1.005 & 1.044 & 1.059 \\
\hline Lemon & 1.011 & 0.171 & 0.174 & 0.342 & 0.42 & 0.378 & 0.411 & 0.415 \\
\hline Apples & 1.083 & 0.516 & 0.585 & 0.522 & 0.552 & 0.645 & 0.588 & 0.642 \\
\hline Oranges & 0.348 & 0.687 & 0.876 & 1.203 & 1.011 & 0.753 & 0.822 & 0.814 \\
\hline Lentil & 0.345 & 0.327 & 0.279 & 0.402 & 0.276 & 0.282 & 0.327 & 0.32 \\
\hline
\end{tabular}

Table 2

Monthly food need (tons) of products from the agricultural subsector including salt and sugar, considered essential and repeated in all the index baskets for Metropolitan Lima and the Amazon Region with respect to a national average

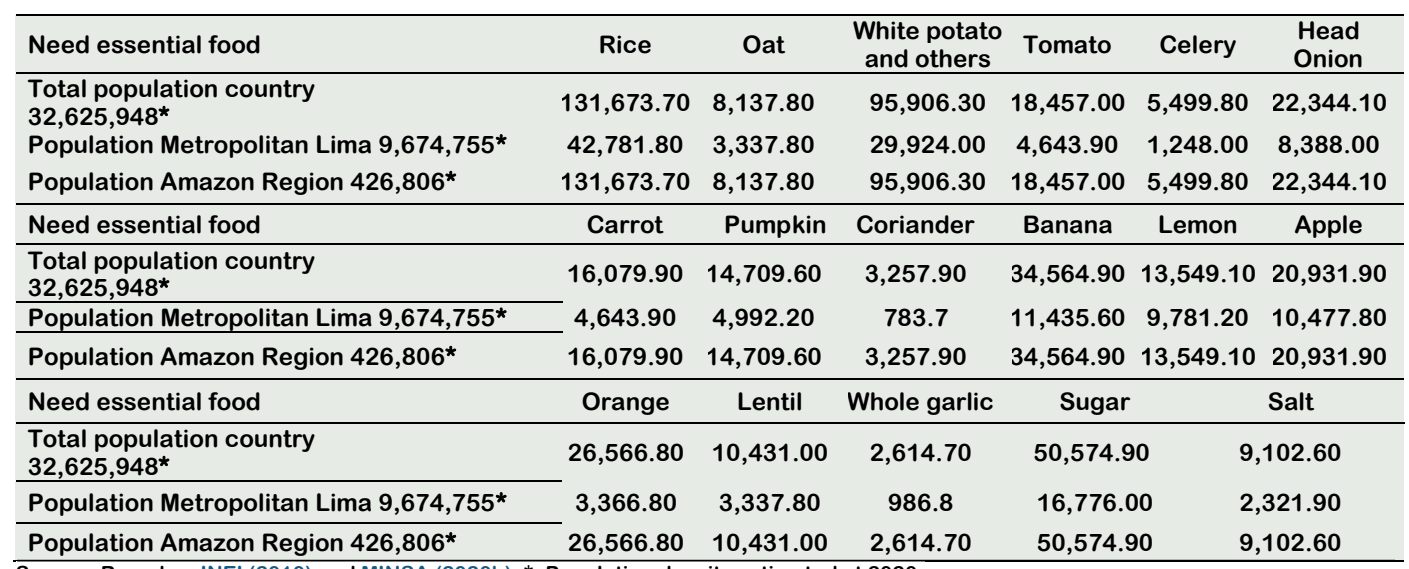

Source: Based on INEI (2010) and MINSA (2020b). *=Population density estimated at 2020.

There are an estimated of $32,625,948$ inhabitants in Peru as of June 2020 (MINSA, $2020 \mathrm{~b}$ ), whom the state would look to protect during the emergency, and which represents at least $484,402.1$ kilos of food per month, regarding agricultural products that are repeated in the index basket that needs to be distributed in all regions of the country (Table 2). Likewise, 159,227.1 kilos per month should be destined for Metropolitan Lima, taken as an example as it is the most populated area and 449,589 kilos per month for the Amazon region, one of the most remote areas of the capital. To maintain the stock, measures must be adopted to address the poor distribution of food, facing the collapse of the share price for transport and energy worldwide since the new pandemic's onset (Ramelli and Wagner, 2020), that cause speculation and an increase in the price index. For example, in February 2020 (INEI, 2020b), 0.15\% more than the consumer price index was registered in the food sector, influenced by higher prices of fresh vegetables with $10.1 \%$.

An increase in the price index is also revealed in the first two months of 2020 in dried vegetables and legumes with $3.6 \%$; fruits with $1.8 \%$, and sugar with variations of up to $9.5 \%$ to $9.7 \%$ (INEI, 2020b). These data reflect a global feeling on price speculation in times of the SARS-CoV-2 health emergency, e.g. Egypt and Jordan have banned imports of garlic, carrots and green ginger from China, Saudi Arabia and the United Arab Emirates. Within cereals, the consumer price index in Peru presents $0.1 \%$ on the rise, mainly influenced by the price of bulk rice with $0.2 \%$ (INEI, 2020b), importing from countries such as Uruguay (58\%), Brazil (38\%), Thailand (3\%), among others (1\%) (MINAGRI, 2020). It represents a total of 70,159 tons in three months of 2020 $(19,909 \mathrm{t}$ in January, 17,811 $\mathrm{t}$ in February and 32,439 tons in March), which corresponds to an average of $17.77 \%$ of the 
monthly needs of the country to cover its index basket per inhabitant (Table 2). This situation makes the competent authorities responsible for ensuring $82.23 \%$ in the country that must be supplied by internal production. This worrying propensity to raise prices for rice, a staple cereal in Peru, is fueled by hoarding stemming from concerns about the COVID-19 pandemic at the international level, from countries such as Vietnam and Cambodia, which decided temporarily freeze new export contracts to examine the domestic supply situation and its export policy (IMF, 2020). On the contrary, the tubers and roots presented a decrease in prices with $-4.3 \%$ (INEI, 2020b). These values, compared to the year 2019 in the same months (January to March) show similar trends (INEI, 2019). Values explained by the similar annual behaviors of the standard deviations of the relationship between farm price and a consumer price for potatoes and goose (Rosales and Mercado, 2020).

\section{Changes and future Policies to be considered}

This global problem leads to make paradigm changes with safety habits and make greater use of locally produced food (Shahidi, 2020). We must look at the pandemic from a perspective where the country can be rescued and restructured with a view to its sustainability, taking the example of other economies such as Taiwan, where work to avoid weak and unsustainable food security platforms (Ruiz, 2020). From the perspective of this problem, the post-pandemic persé, most likely, will take more than a year to be present, so it is time to analyze the possibility that patterns in globalization will unquestionably change in the food sector, so it is suggested to make certain changes and policies such as:

\subsection{Technological and scientific}

Focus current technology towards agriculture. For example, to grant benefit to production restricted by its difficult access to territory, one must make use of the geographical indication (GI) term proposed by Barjolles (2006) and by Giovannucci et al. (2009), to give easy access to geographically distant products to markets. Incorporating digital agriculture (DA) will allow the use of geospatial information technologies that integrate sensors, analysis, and automation to monitor, evaluate and manage soil, climatic and genetic resources in the field (Basso and Antle, 2020).

Science in agriculture. It must be a strategy dominated by government intervention and complemented by various investment methods by society (Sun, 2020).

\subsection{Humanitarian and planning}

Prioritize the small and medium-scale productive agricultural diversity existing in our country. We risk an impending food crisis, unless quick steps are taken to protect the most vulnerable, keep food supply chains alive and mitigate the impacts of the pandemic across the food system, as well as the information it provides us.

Open permanent mobile food corridors. This measure suggests not just itinerant pandemic markets, to channel the direct producer-consumer route and to reduce food dependencies, following all biosafety processes, currently supplied by large imports. Taking a holistic approach to creating a complete food system that operates "all components of food: package identification, education and job creation, food processing, distribution, sales and composting" (Jacobs, 2014).

Peruvian State must implement technical assistance and safe purchasing at a fair price. This decision must be made to reduce the impact on food inefficiency across the country; since there are modest direct effects of income and production, significant changes in organizations, use of inputs, wealth and assets, and risk attitudes (Ruben and Fort, 2012).

Exporting markets should analyze the possibility of seeing the same country as a new (domestic) market destination. While the situation stabilizes, starting with the products that in 2019 had a negative price index behavior in the Agricultural export subsector, such as olives $-23.2 \%$, papaya $9.4 \%$, oil palm $-3.5 \%$ and orange $-2.6 \%$ (INEI, 2020a).

Implementation of biosafety protocols in the commercial and industrial sectors. This is not limited to the food industry alone and should be practiced by everyone, including intermediaries in the consumer food industry (Shahidi, 2020). Furthermore, the visitors, who should be excluded from production facilities, as well as from warehouses and wholesale markets. Supermarkets should reduce staff hours and turnover, and increase contactless delivery services (FAO, 2020c).

Therefore, all countries will be forced to review the state of food security, in the strict sense of quantity, availability and efficiency in their food distribution. Situation that reevaluates analyzing the pandemic in the now and post emergency, from a transdisciplinary perspective, where the impacts can be mitigated using policies according to the nature of each economy. 


\section{Conclusions}

SARS-CoV-2 Pandemic affects the agriculture sector and food security in Peru. The monthly food need values for agricultural products in the country revealed four urgent aspects to be considered: technological, scientific, humanitarian, and planning, in addition to those already implemented, to mitigate the impacts on food safety, now and post-pandemic. These changes and policies must be driven by the Emergency Operations Centers (COE), along with the policies and decisions of the Central Government, and the respective subdirectories from a transdisciplinary prospective. It must be understand the nature of their conditions as the case studies presented here, regarding the minimum food index basket in the Amazon Region (one of the furthest from the Capital) and in Metropolitan Lima (the most populated city in the country).

\section{ORCID}

L. García https://orcid.org/0000-0001-7508-7516

J. Veneros (D) https://orcid.org/0000-0001-6981-4078

D. Tineo $\mathbb{D}$ https://orcid.org/0000-0001-5263-6316

\section{References}

Basso, B.; Antle, J. 2020. Digital agriculture to design sustainable agricultural systems. Nature Sustainability 3(4): 254-256.

Barjolles, D. 2006. Indications géographiques et appellations d'origine contrôlée: un outil de propriété intellectuelle au service du développement rural. Actes du colloque international alimentation et territoires (ALTER), Baeza, Espagne.

Bubolz, M.M.; Sontag, M.S. 2009. Human Ecology Theory In: Boss P., Doherty W.J.; La Rossa, R.; Schumm, W.R.; Steinmetz, S.K. (eds) Sourcebook of Family Theories and Methods. Springer, Boston, MA.

Chen, S.; Brahma, S.; Mackay, J.; Cao, C.; Aliakbarian, B. 2020. The role of smart packaging system in food supply chain. Journal of Food Science 85(3): 517-525.

Deng, S.Q.; Peng, H.J. 2020. Characteristics of and public health responses to the coronavirus disease 2019 outbreak in China. Journal of clinical medicine 9(2): E575.

FAO-Food and Agriculture Organization. 2020a. FAO Food Price Index fell further in March. Available in: http://www.fao.org/worldfoodsituation/foodpricesindex/e $\mathrm{n} /$

FAO - Food and Agriculture Organization. 2020b. Los precios mundiales de los alimentos bajan en marzo. Available in: http://www.fao.org/news/story/es/item/1269130/icode/

FAO-Food and Agriculture Organization. 2020c. FAO A battle plan for ensuring global food supplies during the COVID19 crisis. pandemic. Available in: http://www.fao.org/news/story/en/item/1268059/icode/

IMF - International Monetary Fund. 2020. Police responses to Covid-19. pandemic. Available in:

https://www.imf.org/en/Topics/imf-and-covid19/PolicyResponses-to-COVID-19

INEI - Instituto Nacional de Estadística e Informática. 2010. Consumo per cápita de los principales Alimentos. 2008. 2009. Available in:

https://www.inei.gob.pe/media/MenuRecursivo/publicaci ones_digitales/Est/Lib1028/cap01.pdf

INEI - Instituto Nacional de Estadística e Informática. 2019. Informe Técnico $\mathrm{N}^{\circ} 03$. Variación de los Indicadores de Precios de la Economía. Available in: http://m.inei.gob.pe/media/MenuRecursivo/boletines/info rme-tecnico-de-indicadores-de-precios-febrero2019.pdf

INEI - Instituto Nacional de Estadística e Informática. 2020a. Informe técnico $\mathrm{N}^{\circ}$ 2. Índice de Precios Productor. Available in:
http://m.inei.gob.pe/media/MenuRecursivo/boletines/pre cioproductor02.pdf

INEI - Instituto Nacional de Estadística e Informática. 2020b. Boletín Mensual Indicadores de Precios de la Economía $N^{\circ} 01-2020-I N E I$. Available in:

https://www.inei.gob.pe/media/MenuRecursivo/publicaci ones_digitales/Est/Lib1712/Libro.pdf

Giovannucci, D.; Josling, T.; Kerr, W.; O'Connor, B.; Yeung, M.T. 2009. Guide des indications géographiques: faire le lien entre les produits et leurs origines. ITC.

Jacobs, B.L. 2014. Urban Food Corridors: Cultivating Sustainable Cities. College of Law Faculty Scholarship. Available in: https://trace.tennessee.edu/utk_lawpubl/88

Jansky, S.; Navarre, R.; Bamberg, J. 2019. Introduction to the Special Issue on the Nutritional Value of Potato. American Journal Potato Research 96: 95-97.

Maione, C.; Melgaço, B.R. 2019. Recent applications of multivariate data analysis methods in the authentication of rice and the most analyzed parameters: A review, Critical Reviews in Food Science and Nutrition 59(12): 1868-1879.

MINAGRI - Ministerio de Agricultura y Riego. 2020. Arroz elaborado, abastecimiento y precios. Dirección General de Políticas Agrarias del Ministerio de Agricultura y Riego.

MINSA - Ministerio de Salud. 2020a. Sala situacional Covid-19 Perú. Available in: https://www.gob.pe/minsa

MINSA - Ministerio de Salud. 2020b. Repositorio Único Naciónal de Información en Salud. Estadística poblacional año 2020. Available in:

https://www.minsa.gob.pe/reunis/data/poblacion_estima da.asp

Mouquet, C.; Salvignol, B.; Van Hoan, N.; et al. 2003. Ability of a "very low-cost extruder" to produce instant infant flours at a small scale in Vietnam. Food Chem. 82(2): 249-255.

Ramelli, S.; Wagner, A.F. 2020. Feverish Stock Price Reactions to COVID-19. CEPR Discussion Paper No. DP14511. Available at SSRN: https://ssrn.com/abstract=3560319.

Rosales, G.; Mercado, W. 2020. Effect of changes in food price on the quinoa consumption and rural food security in Peru. Scientia Agropecuaria 11(1): 83-93.

Ruiz, M.A. 2020. A Post-Wuhan-COVID-19 Economic Recovery Proposal: The National Domestic Economic AutoSustainability Model (NDEAS-Model). Available at SSRN 3558883.

Ruben, R.; Fort, R. 2012. The impact of fair trade certification for coffee farmers in Peru. World Development 40(3): 570 582.

Shafiee-Jood, M.; Cai, X. 2016. Reducing food loss and waste to enhance food security and environmental sustainability. Environ. Sci. tech. 50(16): 8432-8443.

Shahidi, F. 2020. Does COVID-19 Affect Food Safety and Security? Journal of Food Bioactives, 9.

Siche, R. 2020. What is the impact of COVID-19 disease on agriculture?. Scientia Agropecuaria 11(1): 3-6.

Sun, Y. 2020. Research of Financial support for Agricultural Development. J. of Bus. and Econ. Dev. 5(1): 21-25.

Velásquez-Milla, D.; Casas, A.; Torres-Guevara, J.; CruzSoriano, A. 2011. Ecological and socio-cultural factors influencing in situ conservation of crop diversity by traditional Andean households in Peru. Journal of Ethnobiology and Ethnomedicine 7(1): 40.

WHO - World Health Organization. 2020. Coronavirus disease 2019 (COVID-19) Situation Report - 108. Available in: https://www.who.int/docs/defaultsource/coronaviruse/situation-reports/20200508covid19-sitrep-109.pdf

Wunderlich, S.M.; Martinez, N.M. 2018. Conserving natural resources through food loss reduction: Production and consumption stages of the food supply chain. Intern. Soil and Water Conservation Research 6(4): 331-339.

Zhao, S.; Lin, Q.; Ran, J.; Musa, S.S.; Yang, G.; Wang, W.; Lou, Y.; Gao, D.; Yang, L.; He, D.; Wang, M.H. 2020. Preliminary estimation of the basic reproduction number of novel coronavirus (2019-nCoV) in China, from 2019 to 2020: A data-driven analysis in the early phase of the outbreak. International Journal of Infectious Diseases 92: 214-217.

Zhu, N.; Zhang, D.; Wang, W.; et al. 2020. A Novel Coronavirus from patients with pneumonia in China, 2019. N Engl $J$ Med 382(8): 727-733. 